\title{
Determination of Total Germanium in Chinese Herbal Remedies by Square-Wave Catalytic Adsorptive Cathodic Stripping Voltammetry at an Improved Bismuth Film Electrode
}

\author{
Shangwei Zhong, ${ }^{1}$ Jiali Su, ${ }^{2}$ Liang Chen, ${ }^{1}$ Jiefeng Tong, ${ }^{3}$ Wenfang Jia, \\ Xiangjun Li, ${ }^{2}$ and Hong Zou ${ }^{1}$ \\ ${ }^{1}$ Department of Chemistry, Capital Normal University, 105 North Xisanhuan Road, Beijing 100048, China \\ ${ }^{2}$ College of Chemistry and Chemical Engineering, University of Chinese Academy of Sciences, 19A Yuquan Road, Beijing 100049, China \\ ${ }^{3}$ Haozhuang Hospital of Yingze District, Taiyuan, Shanxi 030045, China
}

Correspondence should be addressed to Xiangjun Li; lixiangj@ucas.ac.cn and Hong Zou; zouhlixj@163.com

Received 1 July 2013; Accepted 12 August 2013

Academic Editor: Sheng S. Zhang

Copyright ( $(2013$ Shangwei Zhong et al. This is an open access article distributed under the Creative Commons Attribution License, which permits unrestricted use, distribution, and reproduction in any medium, provided the original work is properly cited.

\begin{abstract}
A catalytic adsorptive cathodic stripping voltammetric method on an improved bismuth film electrode (BiFE) for the determination of trace germanium in the presence of pyrogallol has been investigated. A well-defined and sensitive stripping peak of Ge(IV)pyrogallol complex was observed at $-0.79 \mathrm{~V}$ (versus SCE) in a $0.1 \mathrm{M}$ acetate buffer solution ( $\mathrm{pH} 4.8$ ) at a deposition potential of $-0.34 \mathrm{~V}$. The reduction current is catalytically enhanced by adding $\mathrm{KBrO}_{3}$. The experimental variables and potential interference were studied. Compared with the BiFE plated in the solution prepared based on HAc-NaAc without trisodium citrate, the improved $\mathrm{BiFE}$ electrodeposited in the solution of HAc-NaAc containing trisodium citrate displayed a better electroanalytical performance for the determination of germanium(IV). Under the optimized conditions, the detection limit of $\mathrm{Ge}(\mathrm{IV})$ was $60 \mathrm{ng} \mathrm{L}^{-1}$, and the relative standard deviation (RSD) was $3.73 \%$ at $5 \mu \mathrm{g} \mathrm{L}{ }^{-1}$ level $(n=9)$. This method was successfully applied to determine the total germanium in several Chinese herbal remedies.
\end{abstract}

\section{Introduction}

Germanium is an essential trace element in human body and very important for our health. Either overaccumulation or deficiency of germanium could result in various diseases, such as acute renal failure [1]. Germanium compounds display a number of biological activities [2] and are described as antioxidants and immunostimulatory medicine that are used to inhibit the progress of cancer and destroy cancer cells [3]. Organogermanium compounds are considered to promote health and cure diseases [4].

Various analytical methods for determining the trace and ultratrace levels of germanium in medicine [4], food [57], water [8], and soil [5] have been reported, for example, inductively coupled plasma-mass spectrometry (ICP-MS) connected with solid phase extraction $[4,8]$ and combination of hydride generation [9], graphite furnace atomic absorption spectroscopy (GF AAS) $[6,10]$, the spectrophotometric method [11], the hydride generation atomic fluorescence spectrometry method [12], the luminol chemiluminescence flow method [13], and electrochemical methods [5, 7, 14-16]. Among these methods, electrochemical methods show obvious advantages in accuracy, sensitivity, simplicity, low cost, and analytical speed [7]. Adsorptive stripping voltammetry (AdSV) is well suited to determine the trace metal elements. The AdSV procedures developed for the determination of germanium were based on the adsorptive accumulation of a germanium complex on the hanging mercury drop electrode (HMDE) [5, 14-18] or the mercury film electrode (MFE) [7]. Despite the advantages of mercury electrodes for stripping voltammetry, the toxicity of mercury or mercury salts could not be neglected since mercury causes risks to public health 
and unavoidably contaminates the environment in practice. So it is significant to develop alternative electrodes to replace the mercury electrode. In recent decades, bismuth film electrode (BiFE), consisting of a thin bismuth film deposited on a suitable substrate material such as glassy carbon electrode, has been developed and shown a similar performance with mercury electrode $[19,20]$. Since the toxicity of bismuth and its salts is negligible, the BiFE is considered to be environment friendly and might be a satisfying alternative to MFE. Moreover, the BiFE has been widely used to determinate many trace elements such as $\mathrm{Cr}(\mathrm{VI})$ [21, 22], As(III) [23], Co(II) and $\mathrm{Ni}(\mathrm{II})$ [24], and $\mathrm{Cd}(\mathrm{II})$ and $\mathrm{Pb}$ (II) [19]. However, there is no report about the determination of germanium in Chinese herbal remedies by using BiFEs so far. And our group found that the analytical performance of bismuth film electrode was significantly improved by adding citrate to a relatively higher $\mathrm{pH}$ electrodeposition solution [25].

In this study, a new and sensitive analytical method was developed for the determination of germanium based on square-wave catalytic adsorptive cathodic stripping voltammetry using an improved $\mathrm{BiFE}$ as the working electrode and pyrogallol as a complexing ligand. The optimization of the developed technique was achieved by testing the relevant experimental parameters such as $\mathrm{pH}$ value, deposition time, deposition potential, and pyrogallol concentration. The method was successfully applied to determine the trace germanium in several Chinese herbal remedies.

\section{Experimental}

2.1. Apparatus and Reagents. An Autolab PST050 electrochemistry workstation (Radiometer, France) and a microwave digestion system (CEM Model MDS-2000, USA) were used. A three-electrode electrochemical cell system was used with the multimode electrode: the working electrode was a bismuth film electrode (BiFE), the reference electrode was a saturated calomel electrode (SCE), and the auxiliary electrode was a platinum wire. PGENERAL TAS-990 atomic absorption spectrophotometer (Chengdu Superman S\&T Co., Ltd., China).

All the reagents used were of analytical grade purity unless otherwise stated. The $1000 \mathrm{mg} \mathrm{L}^{-1}$ bismuth solution was prepared by dissolving proper amount of $\mathrm{Bi}\left(\mathrm{NO}_{3}\right)_{3} \cdot 5 \mathrm{H}_{2} \mathrm{O}$ (Sinopharm Chemical Reagent Co., Ltd., China) in 5\% $\mathrm{HNO}_{3}$. The germanium standard solutions were made from a stock of $1000 \mu \mathrm{g} \mathrm{mL}^{-1} \mathrm{Ge}(\mathrm{IV})$ (China Iron \& Steel Research Institute) by dilution with water as required. A 0.1 M HAc$\mathrm{NaAc}$ ( $\mathrm{pH}$ 4.8) served as a supporting electrolyte in the analysis step. Stock solution $\left(0.02 \mathrm{~mol} \mathrm{~L}^{-1}\right)$ of pyrogallol was prepared weekly and was stored at $4^{\circ} \mathrm{C}$ in a refrigerator. A $\mathrm{pH}$ meter (PB-10 Sartorius, China) was used for $\mathrm{pH}$ measurements. All aqueous solutions were prepared using ultrapure water (Milli-Q systems, USA).

\subsection{Procedure}

2.2.1. SWAdCSV Measurements of Germanium(IV). Prior to bismuth film formation, the glassy carbon electrode (GCE) was polished with a $0.3-0.05 \mu \mathrm{m}$ alumina slurry on a felt pad, thoroughly rinsed with water, and then sonicated in $5 \% \mathrm{HNO}_{3}$, ethanol, and distilled water. A bismuth film was prepared on a GCE by applying $-1.0 \mathrm{~V}$ for $5 \mathrm{~min}$ in a $100 \mathrm{mg} \mathrm{L}^{-1}$ bismuth(III) and $1 \mathrm{~mol} \mathrm{~L}^{-1}$ acetate buffer media ( $\mathrm{pH} 4.5$ ) with $0.08 \mathrm{~mol} \mathrm{~L}^{-1}$ sodium citrate. Then the threeelectrode system was immersed into $30 \mathrm{~mL} 0.1 \mathrm{~mol} \mathrm{~L}^{-1} \mathrm{HAc}$ $\mathrm{NaAc}(\mathrm{pH} 4.8)$ solution that contained $3 \times 10^{-4} \mathrm{~mol} \mathrm{~L}^{-1}$ $\mathrm{KBrO}_{3} ; 1.3 \times 10^{-3} \mathrm{~mol} \mathrm{~L}^{-1}$ pyrogallol was added into the volumetric cell. The preconcentration potential $(-0.34 \mathrm{~V}$ versus SCE) was applied while the solution was stirred for $150 \mathrm{~s}$. The solutions were stopped and followed by a $15 \mathrm{~s}$ equilibration time. And then the voltammogram recorded by applying a negative scan from -0.5 to $-1.0 \mathrm{~V}$ using the square-wave mode with the following parameters: frequency: $25 \mathrm{~Hz}$; scan increment: $4 \mathrm{mV}$; pulse height: $50 \mathrm{mV}$. After the ground voltammogram has been obtained, the adsorptive stripping experiment was repeated for the addition of proper germanium stock solution. The electrode was cleaned at $-1.3 \mathrm{~V}$ for $10 \mathrm{~s}$ before each measurement.

2.2.2. Determination of Germanium(IV) in Real Samples. The analysis procedure of Chinese herbal remedies sample was as follows: the $0.5 \mathrm{~g}$ sample, $5 \mathrm{~mL} \mathrm{HNO}_{3}$, and $1 \mathrm{~mL} \mathrm{H}_{2} \mathrm{O}_{2}$ were placed into a microwave digestion tank overnight and then digested according to a microwave digestion procedure $\left(5 \mathrm{~min}\right.$ at $180^{\circ} \mathrm{C}$ and then $15 \mathrm{~min}$ at $200^{\circ} \mathrm{C}$ ). After cooling down naturally, the seal pot of the digestion tank was opened, and each solution was heated to empty it of $\mathrm{HNO}_{3}$ on a hotplate $\left(120^{\circ} \mathrm{C}\right)$. Then the digestion tank was cooled down to room temperature and diluted to $25 \mathrm{~mL}$ in a volumetric flask with double-distilled water. These sample solutions were analyzed by SWAdCSV as mentioned above.

\section{Results and Discussion}

3.1. Electrochemical Behavior of Germanium(IV)-Pyrogallol Complex at the Improved Bismuth Film Electrode. Figure 1 shows the SWAdCSV response for $10 \mu \mathrm{g} \mathrm{L}^{-1} \mathrm{Ge}(\mathrm{IV})$ obtained at (c) BiFE plated in $1 \mathrm{~mol} / \mathrm{L}$ acetate buffer $(\mathrm{pH} 4.5)$ without trisodium citrate and (d) the improved BiFE plated in $1 \mathrm{~mol} / \mathrm{L}$ acetate buffer ( $\mathrm{pH} 4.5$ ) containing $0.08 \mathrm{~mol} / \mathrm{L}$ trisodium citrate. And it was obvious that the BiFE (d) electrodeposited in HAc-NaAc medium containing sodium citrate also showed a better electroanalytical performance for determination of Ge(IV) than the BiFE (c). According to Zhang et al. [25] and Nunes and Faria [26], the significant improvement was due to the addition of trisodium citrate that helped form a homogeneous structure by aggregates of spherical particles with a few nanometers in diameter. We also investigated the effect of $\mathrm{KBrO}_{3}$ on the electrochemical behavior of germanium(IV)-pyrogallol complex at the improved bismuth film electrode. No striping peak of pyrogallol was observed (see Figure 1(a)). When Ge(IV) was present together with pyrogallol in the solution, a well-defined stripping peak of the Ge(IV)-pyrogallol complex was observed at a potential of $-0.79 \mathrm{~V}$ (see Figure $1(\mathrm{~b})$ ). When $\mathrm{KBrO}_{3}$ was added into the above solution, the reduction peak current of the complex 


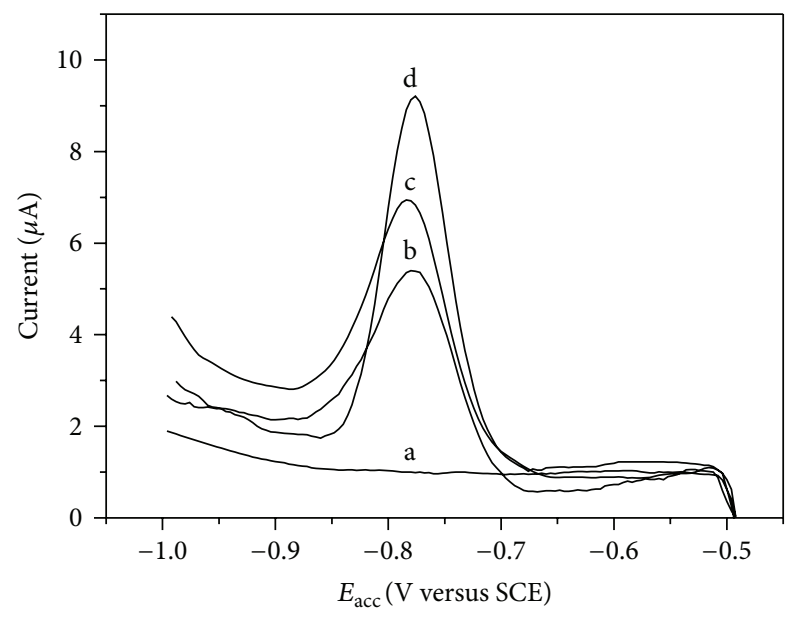

FIGURE 1: Square-wave stripping voltammograms recorded at the improved BiFE plated in $1 \mathrm{~mol} \mathrm{~L}^{-1}$ acetate buffer ( $\mathrm{pH} 4.5$ ) containing $0.08 \mathrm{~mol} / \mathrm{L}$ trisodium citrate $(\mathrm{a}, \mathrm{b}$, and $\mathrm{d}$ ) and the $\mathrm{BiFE}$ (c) plated in $1 \mathrm{~mol} / \mathrm{L}$ acetate buffer $(\mathrm{pH} 4.5)$ without trisodium citrate: (a) $0.1 \mathrm{~mol} \mathrm{~L}^{-1} \mathrm{HAc}-\mathrm{NaAc}(\mathrm{pH} 4.8)+$ pyrogallol $\left(1.3 \times 10^{-3} \mathrm{~mol} \mathrm{~L}^{-1}\right)$; (b) $\mathrm{a}+10 \mu \mathrm{g} \mathrm{L}^{-1} \mathrm{Ge}(\mathrm{IV})$; (c, d) b $+2 \times 10^{-4} \mathrm{~mol} \mathrm{~L}^{-1} \mathrm{KBrO}_{3}$; deposition potential: $-0.34 \mathrm{~V}$; deposition time: $150 \mathrm{~s}$; $\mathrm{SW}$ frequency: $25 \mathrm{~Hz}$; scan increment: $4 \mathrm{mV}$; pulse height: $50 \mathrm{mV}$.

significantly increased (see Figure 1(d)). The catalytic current occurred at the reduction potential of the $\mathrm{Ge}(\mathrm{IV})$-pyrogallol complex owing to the addition of $\mathrm{BrO}_{3}{ }^{-}$. On the basis of the experimental results, the possible reaction mechanism is that $\mathrm{Ge}(\mathrm{IV})$ forms complex with pyrogallol, which subsequently is adsorbed on surface of the BiFE. During the voltammetric scan, $\mathrm{Ge}(\mathrm{IV})$ in the complex is reduced to $\mathrm{Ge}(0)$, which is then oxidized chemically to $\mathrm{Ge}(\mathrm{IV})$ by $\mathrm{BrO}_{3}{ }^{-}$. And then the reoxidized Ge(IV) contributes to the reduction current again, producing the catalytic cycle (see Figure 2).

Cyclic voltammograms (in the range from -0.5 to $-1.0 \mathrm{~V}$ ) of the Ge(IV)-pyrogallol complex with and without Ge(IV) after preconcentration at the BiFE were shown in Figure 3. The pyrogallol (see Figure 3(a)) shows that neither oxidation peak nor reduction peak was observed in the potential window studied here under the selected experiment condition. After adding Ge(IV), the Ge(IV)-pyrogallol complex showed a cathodic peak, at $-0.79 \mathrm{~V}$ (see Figure $3(\mathrm{~b})$ ), arising from the reduction of the $\mathrm{Ge}(\mathrm{IV})$ in $\mathrm{Ge}(\mathrm{IV})$-pyrogallol complexes to $\mathrm{Ge}(0)$. There was no peak observed in the anodic scan, indicating that the reduction of the complex was an irreversible process.

3.2. The Selection of Optimum Experimental Conditions. In order to establish the optimum experimental conditions for a SWAdCSV method to determine germanium(IV) using BiFE, the following parameters that might affect the voltammetric signal of the complex as variables were investigated: $\mathrm{pH}$, pyrogallol and $\mathrm{KBrO}_{3}$ concentrations, adsorptive accumulation time $\left(t_{\mathrm{acc}}\right)$, and accumulation potential $\left(E_{\mathrm{acc}}\right)$ of the germanium(IV)-pyrogallol complexes.
3.2.1. The Effect of the Supporting Electrolyte and pH. In our experiment, the stripping behavior of the Ge(IV)-pyrogallol complex at the improved bismuth film was determined in different supporting electrolytes, including $\mathrm{HAc}, \mathrm{HAc}-\mathrm{NaAc}$, $\mathrm{HNO}_{3}, \mathrm{HCl}, \mathrm{H}_{2} \mathrm{SO}_{4}, \mathrm{NH}_{3}-\mathrm{NH}_{4} \mathrm{Cl}$, and $\mathrm{NH}_{4}$ Ac. The results showed that HAc-NaAc buffer solution was more suitable for the stripping of $\mathrm{Ge}(\mathrm{IV})$-pyrogallol complex due to the welldefined stripping peak, low background current, and high sensitivity.

The effect of $\mathrm{pH}$ on the stripping peak current of Ge(IV)pyrogallol complex was investigated in $0.1 \mathrm{~mol} \mathrm{~L}^{-1} \mathrm{HAc}-$ NaAc solutions at different $\mathrm{pH}$ values (see Figure 4). The peak currents of the complex varied with the change of $\mathrm{pH}$ from 4.0 to 5.4. The $\mathrm{pH}$ of the solution also had an influence on the peak potentials, which changed to more negative values for higher $\mathrm{pH}$ values. For example, for a $\mathrm{pH}$ of 4.0, the peak potential of $\mathrm{Ge}(\mathrm{IV})$ was $-743 \mathrm{mV}$; for a $\mathrm{pH}$ of 5.4 , the peak potential was $-821 \mathrm{mV}$. The stripping peak current reached the maximum at $\mathrm{pH} 4.8$. When $\mathrm{pH}$ was higher than 4.8 , the stripping peak currents began to decrease. Thus, the optimum condition of $\mathrm{pH}$ values is $\mathrm{pH} 4.8$.

3.2.2. The Effect of Pyrogallol Concentration. The effect of the pyrogallol concentration on peak current of the Ge(IV)pyrogallol complex was investigated in the range $3.0 \times 10^{-4}$ $1.5 \times 10^{-3} \mathrm{~mol} \mathrm{~L}^{-1}$ (see Figure 5). At low pyrogallol concentrations, the complexation of $\mathrm{Ge}(\mathrm{IV})$ with pyrogallol was not completed. So the peak currents increased with increasing pyrogallol concentration up to $1.3 \times 10^{-3} \mathrm{~mol} \mathrm{~L}^{-1}$. When pyrogallol concentration was higher than $1.3 \times 10^{-3} \mathrm{~mol} \mathrm{~L}^{-1}$, the peak current started to decrease. It is possible that there was competitive adsorption of the free pyrogallol on the electrode surface. Therefore, for the following work, a pyrogallol concentration of $1.3 \times 10^{-3} \mathrm{~mol} \mathrm{~L}^{-1}$ was used.

3.2.3. The Effect of $\mathrm{KBrO}_{3}$ Concentration. The effect of $\mathrm{KBrO}_{3}$ concentrations on the stripping peak current of the Ge(IV)pyrogallol complex was studied. The results indicated that $\mathrm{KBrO}_{3}$ enhanced the stripping sensitivity of the complex. At $\mathrm{KBrO}_{3}$ concentrations smaller than $3 \times 10^{-4} \mathrm{~mol} \mathrm{~L}^{-1}$, the peak height increased rapidly with increasing $\mathrm{KBrO}_{3}$ concentration, but, subsequently, it increases slowly, and distortion of the cathodic side of the peak was observed. Therefore, the concentration $3 \times 10^{-4} \mathrm{~mol} \mathrm{~L}^{-1}$ was used in the further experiments.

3.2.4. The Effect of Accumulation Potential and Accumulation Time. The effects of the accumulation potential and accumulation time on the stripping peak current of Ge(IV)pyrogallol complex on the improved bismuth film electrode were studied. The preconcentration potential was examined over the range from -0.34 to $-0.38 \mathrm{~V}$ in the experiment with a deposition time $180 \mathrm{~s}$ and is shown in Figure 6. The largest peak current was obtained at a deposition potential of $-0.34 \mathrm{~V}$, and the peak current decreased slowly at more negative potentials. Electrostatic exclusion may be responsible for the observed effect. Since the germanium(IV)-pyrogallol 


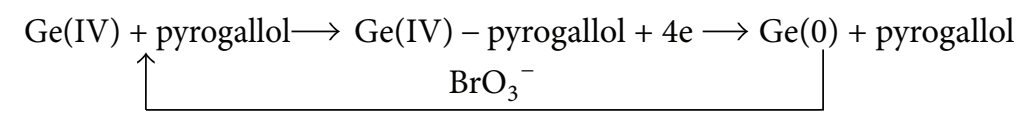

FIGURE 2

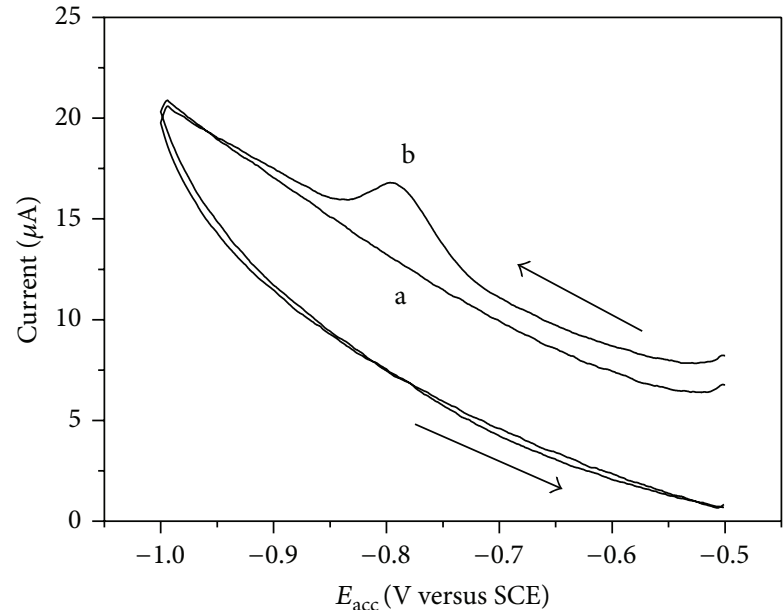

FIgUre 3: Cyclic voltammograms recorded at a BiFE plated in $1 \mathrm{~mol} \mathrm{~L}^{-1}$ acetate buffer ( $\mathrm{pH} 4.5$ ) containing $0.08 \mathrm{~mol} / \mathrm{L}$ trisodium citrate: (a) $0.1 \mathrm{~mol} \mathrm{~L}^{-1} \mathrm{HAc}-\mathrm{NaAc}(\mathrm{pH} 4.8)+$ pyrogallol $(1.3 \times$ $\left.10^{-3} \mathrm{~mol} \mathrm{~L}^{-1}\right)+2 \times 10^{-4} \mathrm{~mol} \mathrm{~L}^{-1} \mathrm{KBrO}_{3}$; (b) a $+\mathrm{Ge}(\mathrm{IV})\left(20 \mu \mathrm{g} \mathrm{L}^{-1}\right)$; deposition potential: $-0.34 \mathrm{~V}$; deposition time: $150 \mathrm{~s}$; potential scan rate: $50 \mathrm{mV} \mathrm{s}^{-1}$.

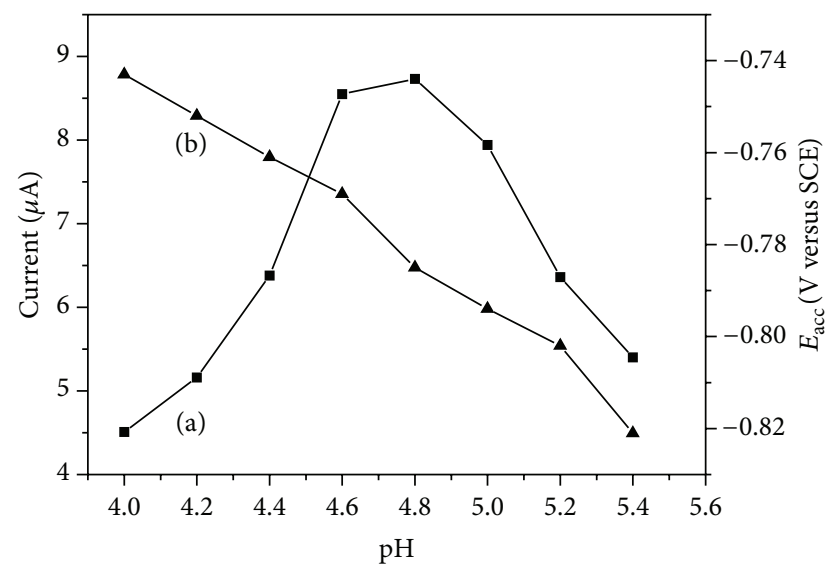

FIGURE 4: The effect of $\mathrm{pH}$ of the supporting electrolyte on the stripping peak current (a) and the position of peak (b) of Ge(IV)pyrogallol complex in $0.1 \mathrm{~mol} \mathrm{~L}^{-1} \mathrm{HAc}-\mathrm{NaAcn}+$ pyrogallol $(1.3 \times$ $\left.10^{-3} \mathrm{~mol} \mathrm{~L}^{-1}\right)+3 \times 10^{-4} \mathrm{~mol} \mathrm{~L}^{-1} \mathrm{KBrO}_{3} ; \mathrm{Ge}(\mathrm{IV})$ concentration: $10 \mu \mathrm{g} \mathrm{L}^{-1}$. Other conditions as in Figure 1.

complex appears to be negatively charged, a more positive potential is favorable for its adsorption at BiFE, but too positive potential would damage the BiFE. Thus, $-0.34 \mathrm{~V}$ was selected as the accumulation potential in the further procedures.

The dependence of the maximum stripping peak current on the accumulation time was examined for samples

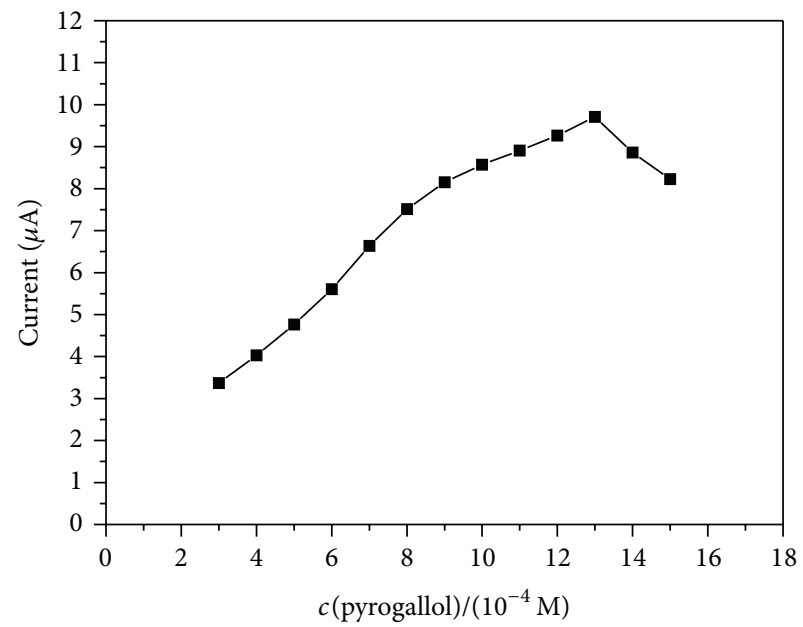

FIGURE 5: The effect of the pyrogallol concentration on the stripping peak current of $\mathrm{Ge}(\mathrm{IV})$-pyrogallol complex in $0.1 \mathrm{~mol} \mathrm{~L}^{-1} \mathrm{HAc}$ $\mathrm{NaAc}+3 \times 10^{-4} \mathrm{~mol} \mathrm{~L}^{-1} \mathrm{KBrO}_{3}$; Ge(IV) concentration: $10 \mu \mathrm{g} \mathrm{L}^{-1}$. Other conditions as in Figure 1.

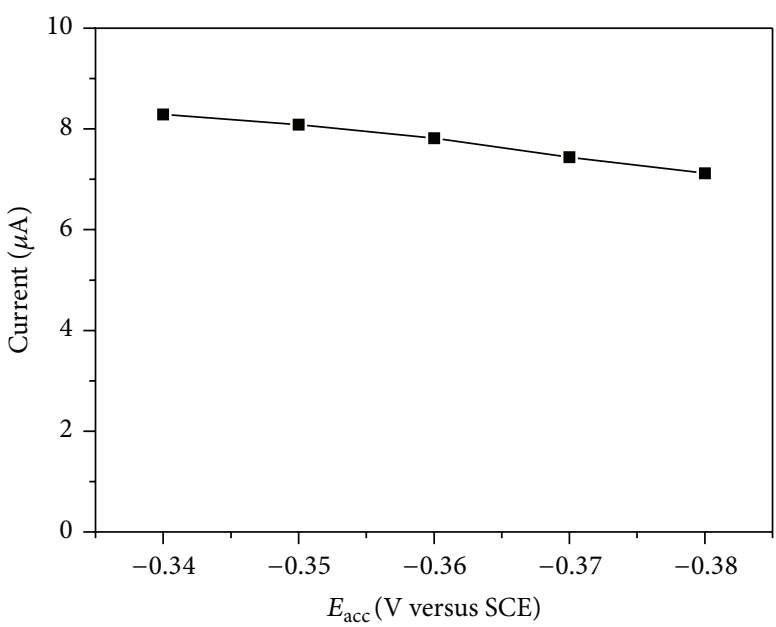

FIGURE 6: The effect of preconcentration potential on the stripping peak current of Ge(IV)-pyrogallol complex. Other conditions as in Figure 1.

containing $5 \mu \mathrm{g} \mathrm{L}^{-1}$ and $10 \mu \mathrm{g} \mathrm{L}^{-1}$ germanium(IV) in the range of $0-270 \mathrm{~s}$ (see Figure 7 ). The maximum peak height was observed at $150 \mathrm{~s}$ and $210 \mathrm{~s}$ for $10 \mu \mathrm{g} \mathrm{L}^{-1}$ and $5 \mu \mathrm{g} \mathrm{L} \mathrm{L}^{-1}$ germanium(IV), respectively, and was constant during the longer time. Therefore, a deposition time of $180 \mathrm{~s}$ was selected for the rest of this work. However, in the real sample analysis, the deposition time should be delayed due to the low concentration of germanium(IV). 
TABLE 1: Results for the determination of total germanium in several Chinese herbal remedies and the recovery rate.

\begin{tabular}{|c|c|c|c|c|c|c|}
\hline \multirow{2}{*}{ Sample } & \multirow{2}{*}{ GF AAS } & \multirow{2}{*}{ Found $^{\mathrm{a}}$} & \multirow{2}{*}{ RSD (\%) } & \multicolumn{3}{|c|}{ Recovery } \\
\hline & & & & Addition & Found $^{\mathrm{a}}$ & Recovery rate $(\%)$ \\
\hline Cultivated ganoderma lucidum $\left(\mu \mathrm{g} \mathrm{g}^{-1}\right)^{\mathrm{b}}$ & 3.22 & 3.18 & 1.41 & 10.00 & 13.15 & 99.7 \\
\hline Wild ganoderma lucidum $\left(\mu \mathrm{g} \mathrm{g}^{-1}\right)^{\mathrm{b}}$ & 1.29 & 1.32 & 3.05 & 5.00 & 6.34 & 100.4 \\
\hline Polygonum multiflorum thunb $\left(\mu \mathrm{gg}^{-1}\right)^{\mathrm{b}}$ & 0.47 & 0.49 & 3.62 & 5.00 & 5.38 & 97.8 \\
\hline
\end{tabular}

${ }^{a} n=3$.

${ }^{\mathrm{b}}$ From a pharmacy, Beijing, China.

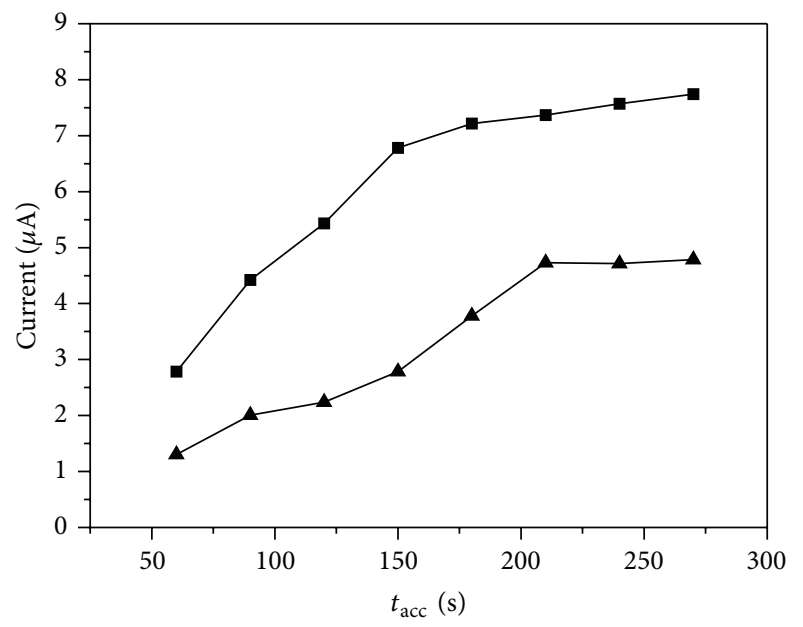

Figure 7: The dependence of the stripping current of Ge(IV)pyrogallol complex on the accumulation time, pyrogallol concentration $1.3 \times 10^{-3} \mathrm{~mol} \mathrm{~L}^{-1}, 5 \mu \mathrm{g} \mathrm{L}^{-1}(\mathbf{\Delta}) \mathrm{Ge}(\mathrm{IV})$, and $10 \mu \mathrm{g} \mathrm{L}^{-1}(\mathbf{\square})$ $\mathrm{Ge}(\mathrm{IV})$. Other conditions as in Figure 1.

3.3. Linear Range, Detection Limit, and Reproducibility. Under the optimum experimental conditions, a linear relationship between the peak current and the germanium(IV) concentration was obtained in the range of 0.5 to $17 \mu \mathrm{g} \mathrm{L}-1$ (see Figure 8) in the presence of dissolved oxygen. The linear regression equation was $i=0.886 c+0.856$, where $i$ and $c$ are peak current $(\mu \mathrm{A})$ and $\mathrm{Ge}(\mathrm{IV})$ concentration $\left(\mu \mathrm{g} \mathrm{L}^{-1}\right)$, respectively, and the linear correlation coefficient $\left(R^{2}\right)$ was 0.995. The voltammogram obtained for the lowest concentration with an accumulation time of $540 \mathrm{~s}$ was $60 \mathrm{ng} \mathrm{L}^{-1}$, and the relative standard deviation from the nine parallel determinations of $\mathrm{Ge}(\mathrm{VI})$ at $5 \mu \mathrm{g} \mathrm{L} \mathrm{L}^{-1}$ was $3.73 \%$.

3.4. The Interference. Two major sources of interference were investigated. First, potential interferences from other metal ions in the determination of germanium(IV) were studied. Various ions were examined as possible interferences by the addition of the interfering ions to a solution containing $10 \mu \mathrm{g} \mathrm{L}^{-1} \mathrm{Ge}(\mathrm{IV})$ using the optimum experimental conditions. The results indicated that a 500 -fold excess of $\mathrm{Mg}(\mathrm{II})$, a 200 -fold excess of $\mathrm{Cd}(\mathrm{II}), \mathrm{Co}(\mathrm{II}), \mathrm{Cr}$ (III), $\mathrm{Fe}(\mathrm{III}), \mathrm{Ni}(\mathrm{II})$, $\mathrm{Pb}(\mathrm{II}), \mathrm{Zn}(\mathrm{II})$, and $\mathrm{Mn}(\mathrm{II})$, and a 5 -fold excess of $\mathrm{Sn}(\mathrm{II})$, $\mathrm{Sb}$ (III) did not interfere in the determination of Ge(IV) with an error less than $5 \%$.

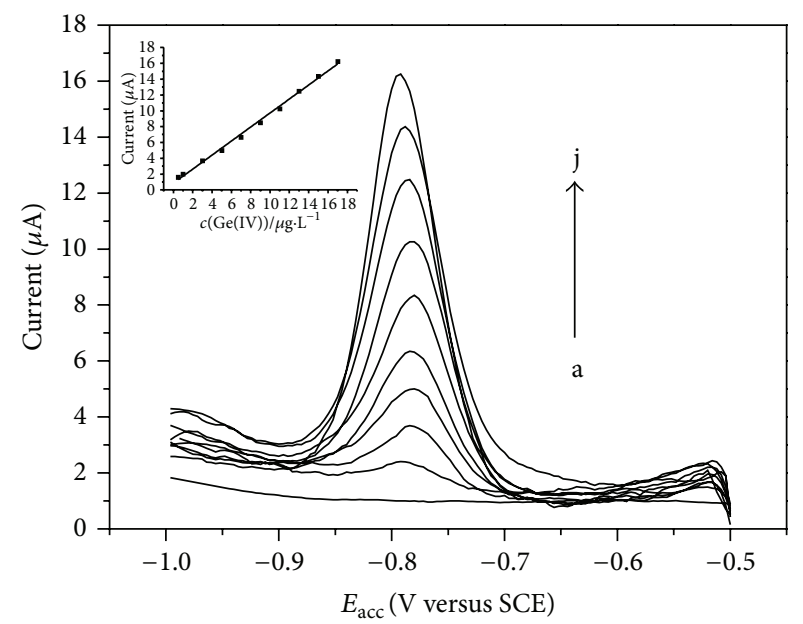

FIGURE 8: Adsorptive stripping curves of Ge(IV) concentrations from 0 to $17 \mu \mathrm{gL}^{-1}(\mathrm{a}-\mathrm{j})$ (a: $0, \mathrm{~b}: 0.5$, and $\mathrm{c}-\mathrm{j}$ : $1-17$ (in the step of $\left.2 \mu \mathrm{g} \mathrm{L}^{-1}\right)$ ) obtained at the bismuth film electrode. Pyrogallol concentration $1.3 \times 10^{-3} \mathrm{~mol} \mathrm{~L}^{-1}$. Other conditions as in Figure 1 .

In addition, naturally occurring organic compounds can be adsorbed onto the electrode surface and interfere with the adsorptive voltammetric analysis. The interference of anionic surfactant sodium dodecylbenzene sulfonate (SDBS) and the cationic surfactant cetyltrimethylammonium bromide (CTMAB) was investigated. The Ge(IV) signal diminished by 49 and $67 \%$ after addition of $3.48 \mathrm{mg} \mathrm{L}^{-1}$ SDBS and $3.64 \mathrm{mg} \mathrm{L}^{-1}$ CTMAB, respectively.

3.5. Analysis of Samples. In our experiment, the developed method was applied to determine of total germanium in several Chinese herbal remedies: cultivated ganoderma lucidum, wild ganoderma lucidum, and polygonum multiflorum thunb. The samples were pretreated according to the procedure described in Section 2, and then the sample solutions were used for germanium determination. The results are listed in Table 1, and the recovery rate is from 97.8 to $100.4 \%$. And the accuracy of the proposed method was assessed by comparing the results obtained by SWAdCSV with those obtained by GF AAS.

\section{Conclusions}

In this study, we developed a new method for determining the total germanium by square-wave catalytic adsorptive 
stripping voltammetry at an improved bismuth film electrode. And we got the optimum condition for the germanium determination. Total germanium in several Chinese herbal remedies was determined by using this optimized method, and the results were consistent with those obtained by GF AAS. It is demonstrated that the catalytic adsorptive $\mathrm{Ge}(\mathrm{IV})$-pyrogallol- $\mathrm{KBrO}_{3}$ system is suitable for determining trace germanium with high sensitivity, simplicity, and good reproducibility and with being environment friendly.

\section{Conflict of Interests}

The authors have declared no conflict of interests.

\section{Authors' Contribution}

Shangwei Zhong and Jiali Su have equally contributed to this work.

\section{Acknowledgment}

This work was supported by the Beijing City Board of Education Fund (no. KM201110028009).

\section{References}

[1] N. Nagata, T. Yoneyama, and K. Yanagida, "Accumulation of germanium in the tissues of a long-term user of germanium preparation died of acute renal failure," Journal of Toxicological Sciences, vol. 10, no. 4, pp. 333-341, 1985.

[2] H. Aso, F. Suzuki, and T. Yamaguchi, "Induction of interferon and activation of NK cells and macrophages in mice by oral administration of Ge-132, an organic germanium compound," Microbiology and Immunology, vol. 29, no. 1, pp. 65-74, 1985.

[3] G. B. Gerber and A. Léonard, "Mutagenicity, carcinogenicity and teratogenicity of germanium compounds," Mutation Research, vol. 387, no. 3, pp. 141-146, 1997.

[4] P. Krystek and R. Ritsema, "Analytical product study of germanium-containing medicine by different ICP-MS applications," Journal of Trace Elements in Medicine and Biology, vol. 18, no. 1, pp. 9-16, 2004.

[5] S. Jinhui and J. Kui, "Adsorptive complex catalytic polarographic determination of germanium in soils and vegetables," Analytica Chimica Acta, vol. 309, no. 1-3, pp. 103-109, 1995.

[6] M. McMahon, F. Regan, and H. Hughes, "The determination of total germanium in real food samples including Chinese herbal remedies using graphite furnace atomic absorption spectroscopy," Food Chemistry, vol. 97, no. 3, pp. 411-417, 2006.

[7] S. Y. Ly, S. S. Sang, K. K. Sung, S. J. Young, and H. L. Chang, "Determination of $\mathrm{Ge}(\mathrm{IV})$ in rice in a mercury-coated glassy carbon electrode in the presence of catechol," Food Chemistry, vol. 95, no. 2, pp. 337-343, 2006.

[8] A. Sabarudin, T. Umemura, and S. Motomizu, "Chitosan functionalized with di-2-propanolamine: its application as solid phase extractant for the determination of germanium in water samples by ICP-MS," Microchemical Journal, vol. 99, no. 1, pp. 34-39, 2011.

[9] K. Jin, Y. Shibata, and M. Morita, "Determination of germanium species by hydride generation-Inductively coupled argon plasma mass spectrometry," Analytical Chemistry, vol. 63, no. 10, pp. 986-989, 1991.
[10] Y. Sohrin, K. Isshiki, T. Kuwamoto, and E. Nakayama, "Determination of germanium by graphite-furnace atomic-absorption spectrometry," Talanta, vol. 34, no. 3, pp. 341-344, 1987.

[11] L. Zaijun, T. Jian, L. Huizhen, Z. Xia, and Y. Rui, "Determination of trace amounts of germanium in food and fruit by spectrophotometry with p-methybenzeneazosalicylflurone," Journal of Food Composition and Analysis, vol. 20, no. 1, pp. 1-6, 2007.

[12] S. Jianbo, T. Zhiyong, T. Chunhua, C. Quan, and J. Zexiang, "Determination of trace amounts of germanium by flow injection hydride generation atomic fluorescence spectrometry with on-line coprecipitation," Talanta, vol. 56, no. 4, pp. 711-716, 2002.

[13] T. Fujiwara, K. Kurahashi, T. Kumamaru, and H. Sakai, "Luminol chemiluminescence with heteropoly acids and its application to the determination of arsenate, germanate, phosphate and silicate by ion chromatography," Applied Organometallic Chemistry, vol. 10, no. 9, pp. 675-681, 1996.

[14] C. Sun, Q. Gao, and L. Liu, "Adsorptive stripping measurements of germanium(IV) in the presence of pyrogallol," Talanta, vol. 42, no. 7, pp. 881-884, 1995.

[15] Y.-H. Li, X.-H. Chen, M.-H. Huang, and F.-Q. Zhou, "Catalytic adsorptive stripping voltammetry of germanium(IV) in the presence of gallic acid and vanadium(IV)-EDTA," Electroanalysis, vol. 19, no. 6, pp. 704-708, 2007.

[16] J. L. M. Álvarez, J. A. G. Calzón, and J. M. L. Fonseca, “Squarewave voltammetry of the o-catechol-Ge(IV) catalytic system after adsorptive preconcentration at a hanging mercury drop electrode," Talanta, vol. 53, no. 4, pp. 721-731, 2001.

[17] J. C. Aguilar and J. De Gyves, "Determination of germanium(IV) in sulphide ores by differential pulse polarography in pyrogallol-sulfuric acid media," Analytica Chimica Acta, vol. 306, no. 2-3, pp. 243-247, 1995.

[18] C. Sun, Q. Gao, J. Xi, and H. Xu, "Determination of germanium(IV) by catalytic cathodic stripping voltammetry," Analytica Chimica Acta, vol. 309, no. 1-3, pp. 89-93, 1995.

[19] J. Wang, J. Lu, S. B. Hocevar, P. A. M. Farias, and B. Ogorevc, "Bismuth-coated carbon electrodes for anodic stripping voltammetry," Analytical Chemistry, vol. 72, no. 14, pp. 3218-3222, 2000.

[20] L. Lin, S. Thongngamdee, J. Wang, Y. Lin, O. A. Sadik, and S.-Y. Ly, "Adsorptive stripping voltammetric measurements of trace uranium at the bismuth film electrode," Analytica Chimica Acta, vol. 535, no. 1-2, pp. 9-13, 2005.

[21] L. Lin, N. S. Lawrence, S. Thongngamdee, J. Wang, and Y. Lin, "Catalytic adsorptive stripping determination of trace chromium (VI) at the bismuth film electrode," Talanta, vol. 65, no. 1, pp. 144-148, 2005.

[22] E. O. Jorge, M. M. Rocha, I. T. E. Fonseca, and M. M. M. Neto, "Studies on the stripping voltammetric determination and speciation of chromium at a rotating-disc bismuth film electrode," Talanta, vol. 81, no. 1-2, pp. 556-564, 2010.

[23] L. Jiajie and Y. Nagaosa, "Cathodic stripping voltammetric determination of As(III) with in situ plated bismuth-film electrode using the catalytic hydrogen wave," Analytica Chimica Acta, vol. 593, no. 1, pp. 1-6, 2007.

[24] M. Morfobos, A. Economou, and A. Voulgaropoulos, "Simultaneous determination of nickel(II) and cobalt(II) by square wave adsorptive stripping voltammetry on a rotating-disc bismuthfilm electrode," Analytica Chimica Acta, vol. 519, no. 1, pp. 57-64, 2004.

[25] Q. Zhang, S. Zhong, J. Su, X. Li, and H. Zou, "Determination of trace chromium by square-wave adsorptive cathodic stripping 
voltammetry at an improved bismuth film electrode," Journal of the Electrochemical Society, vol. 160, no. 4, pp. H237-H242, 2013.

[26] L. M. S. Nunes and R. C. Faria, "The influence of the electrodeposition conditions on the electroanalytical performance of the bismuth film electrode for lead determination," Electroanalysis, vol. 20, no. 20, pp. 2259-2263, 2008. 

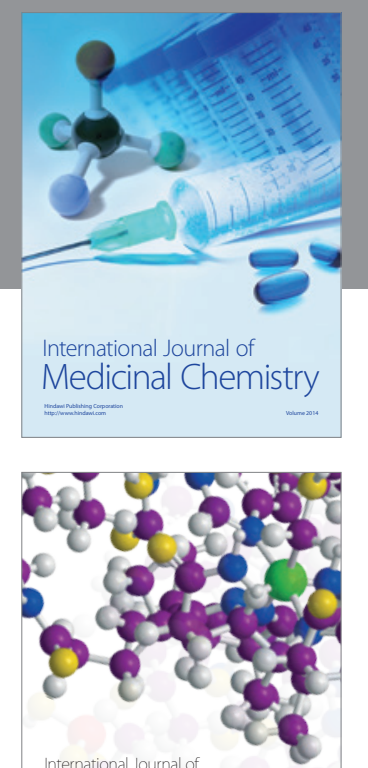

\section{Carbohydrate} Chemistry

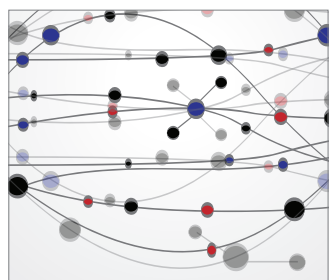

The Scientific World Journal
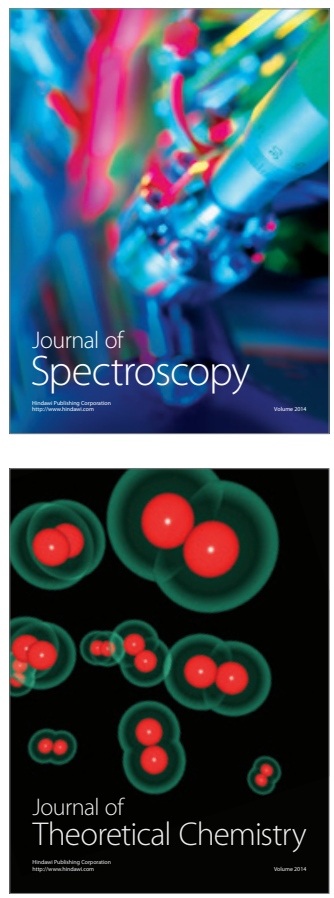
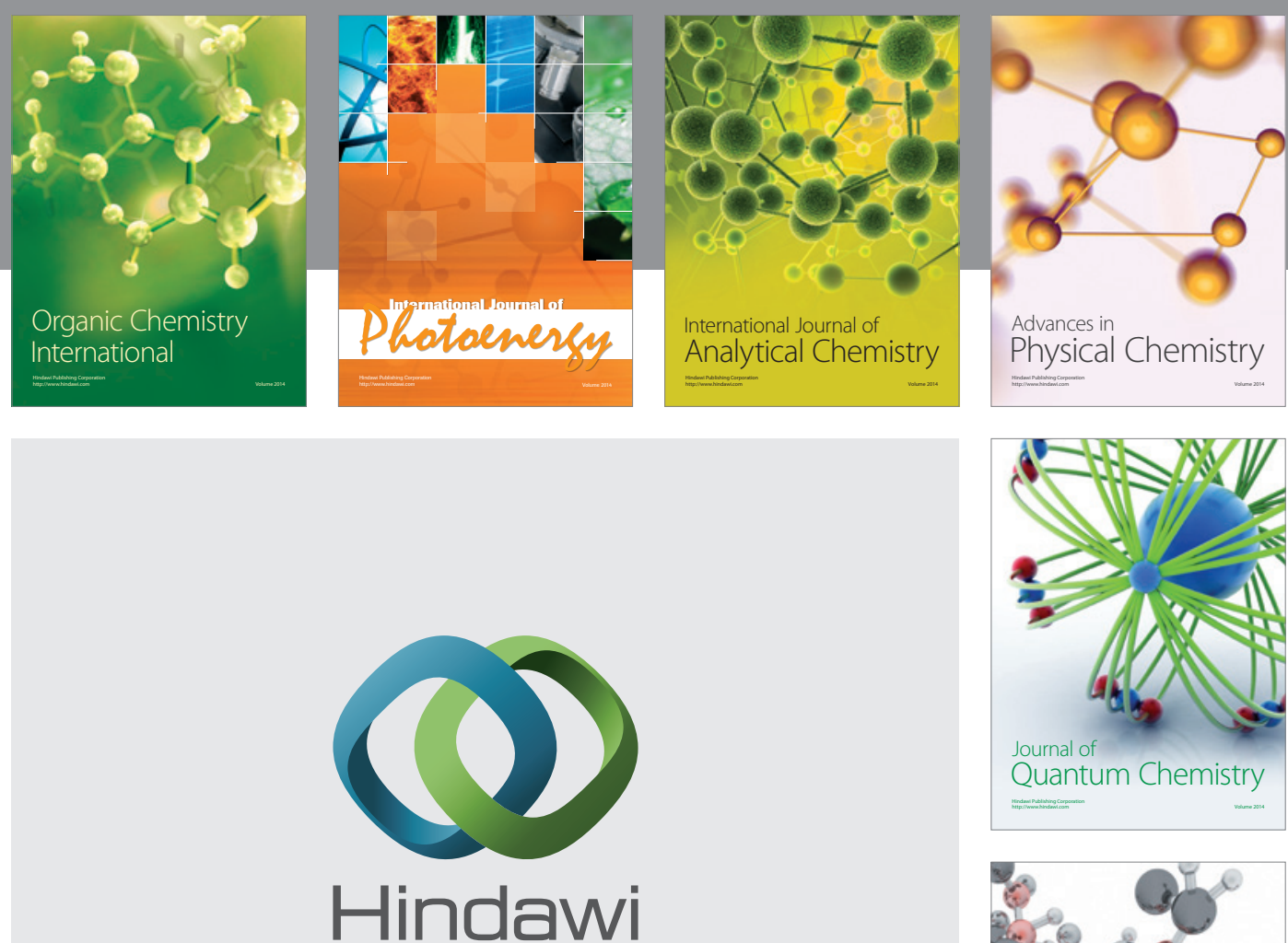

Submit your manuscripts at

http://www.hindawi.com

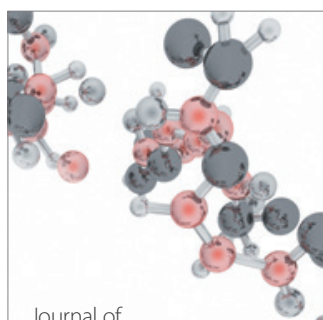

Analytical Methods

in Chemistry

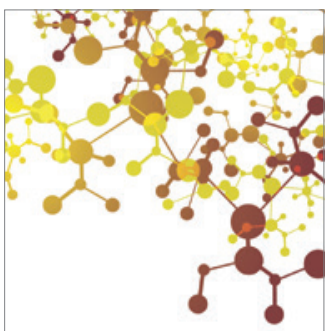

Journal of

Applied Chemistry

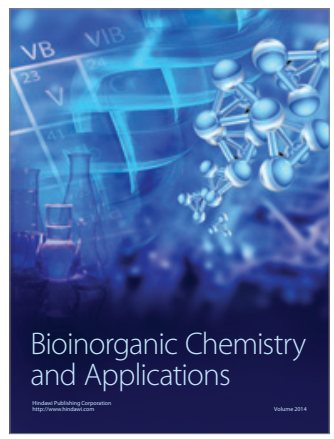

Inorganic Chemistry
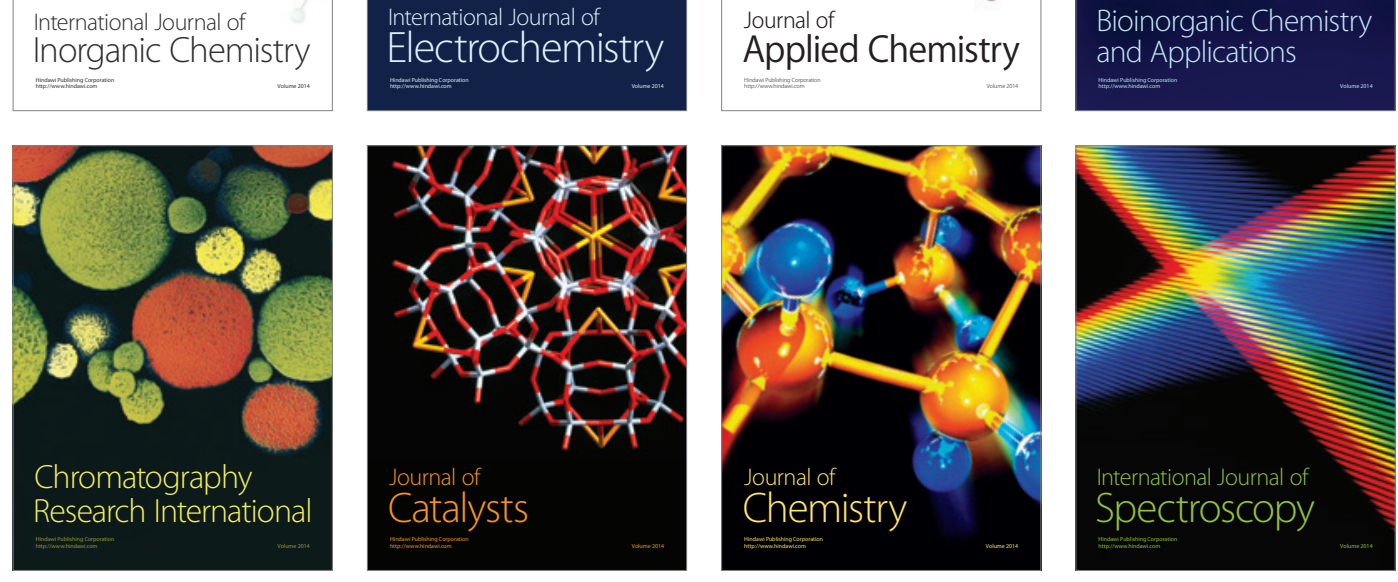